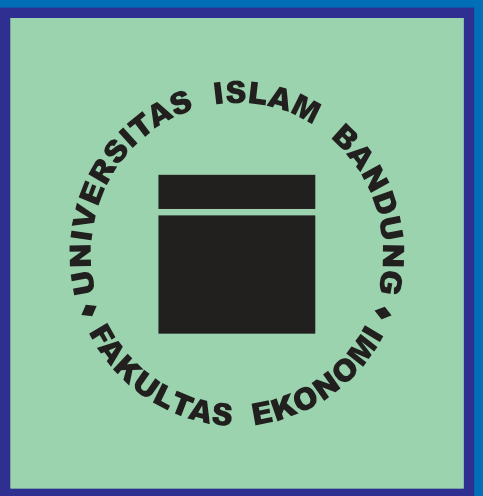

Vol.21 No.2

September 2020

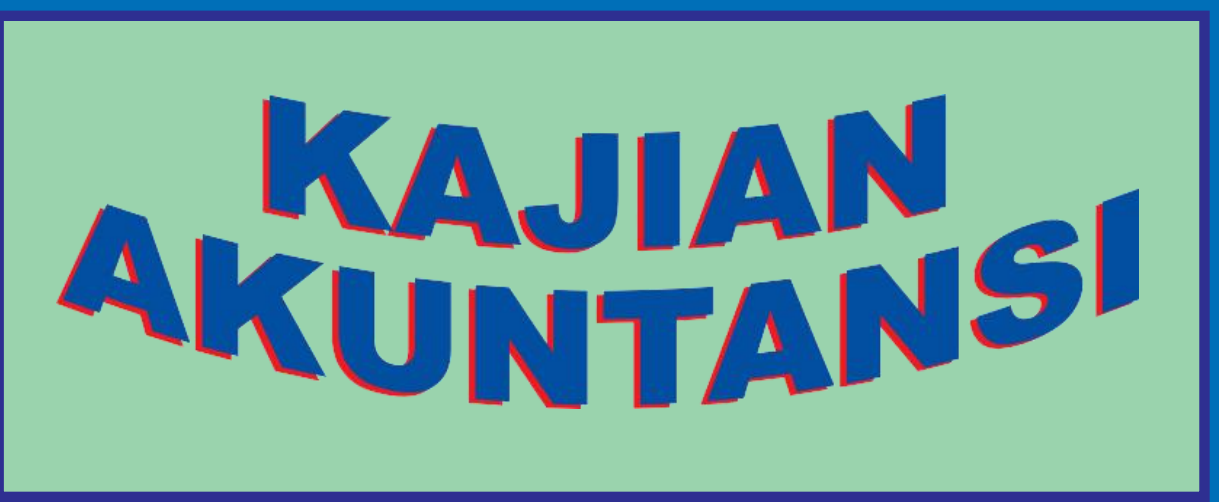

ISSN : 1693 - 0614 e-ISSN : 2581 - 074X
Deliana, Abdul Rahman

Ilham Hidayah Napitupulu, Anggiat Situngkir,

Chairunnisa Arfanni

Edi Sukarmanto, Magnaz Lestira Oktaroza, Karina Nur Astari

Eka Nurmala Sari, Muhyarsyah, Nunung Sri Wahyuni

Nurhayati, Muhammad Kevin Aprilio

Uli Wildan Nuryanto, Masyhudzulhak

Djamil MZ, Achmad Hidayat Sutawidjaya, Ahmad Badawi Saluy.

Riyang Mardini

Annisa Nadiyah

Rahmani

Diamonalisa Sofianty, Lena Herlina.
Efektivitas Audit Internal Pada Perguruan Tinggi Negeri Di Provinsi Sumatera Utara.

Pengaruh Transfer Pricing Dan Profitabilitas Terhadap Tax Avoidance.

Related Party Transaction Memperkuat Pengaruh Political Connection Terhadap Audit Delay?

Pengaruh Sistem Pengendalian Intern Pemerintah Dan Ketersediaan Anggaran Terhadap Efektivitas Penerapan Sistem Informasi Keuangan Daerah Pada Pemerintah Provinsi Dan Kabupaten/Kota Se-Sumatera Utara.

Pengaruh Rasio Solvabilitas Terhadap Kondisi Financial Distress

Implikasi Keunggulan Bersaing Terhadap Kinerja Organisasi Pada Sektor Industri Manufaktur Kimia di Provinsi Banten

Pengaruh Kinerja ICSR Terhadap Readability ICSR Menggunakan Gunning Fog Dan Flesch-Kincaid Indeks Dengan Size, Kinerja Keuangan, Leverage Dan Growth Sebagai Variabel Kontrol.

Dampak Covid-19 Terhadap Harga Saham Dan Kinerja Keuangan Perusahaan

Pengaruh Pengungkapan Corporate Social Responsibility Dan Mekanisme Good Corporate Governance Terhadap Tax Avoidance

Diterbitkan oleh :

ISSN

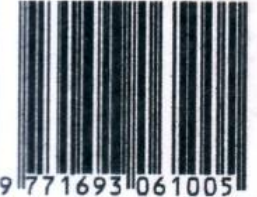

( P 2 U )

Pusat Penerbitan Universitas 


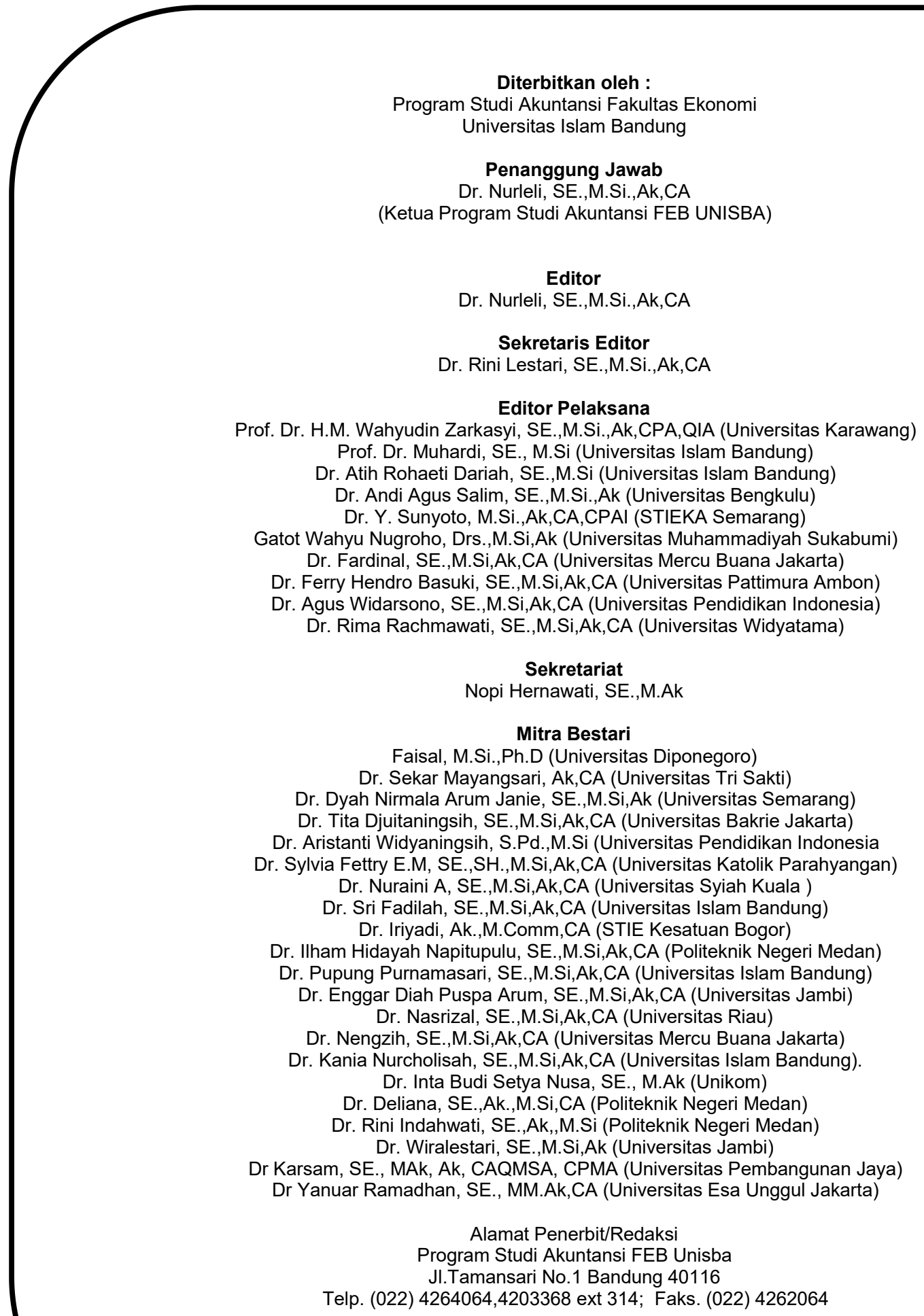

Terbit dua kali dalam setahun : Maret dan September Terbit pertama kali Maret 2003

Redaksi menerima naskah berupa artikel penelitian maupun artikel hasil pengkajian. Pendapat yang dimuat dalam jurnal ini sepenuhnya pendapat pribadi penulis ,

tidak mencerminkan pendapat redaksi,

dan telah disajikan menurut sistematika yang ditetapkan pada halaman akhir jurnal ini . 


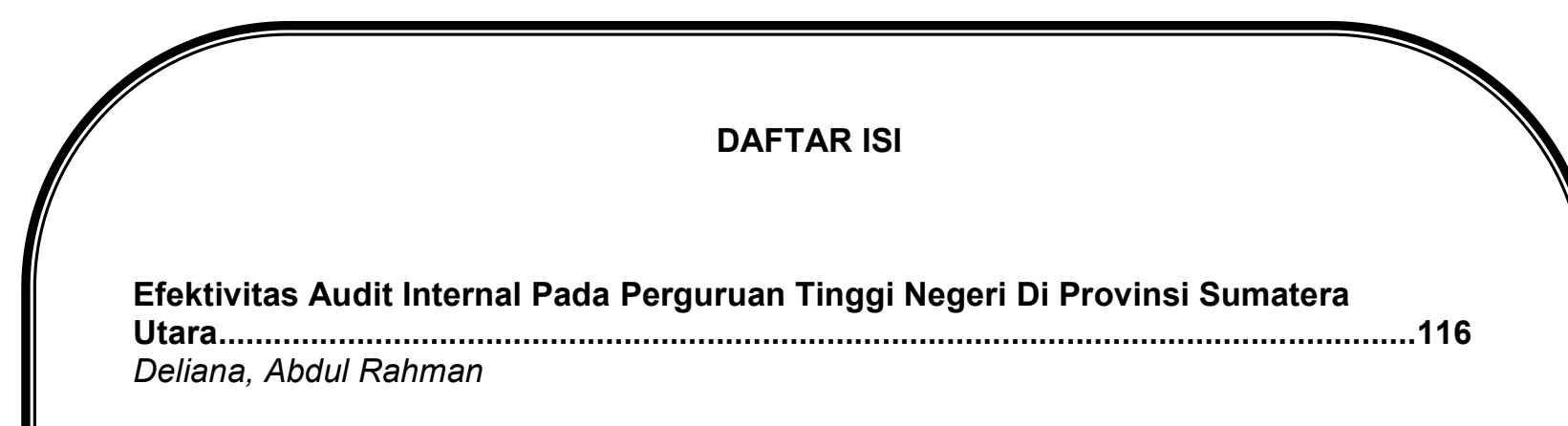

Pengaruh Transfer Pricing Dan Profitabilitas Terhadap Tax Avoidance .126

Ilham Hidayah Napitupulu, Anggiat Situngkir, Chairunnisa Arfanni

Related Party Transaction Memperkuat Pengaruh Political Connection

Terhadap Audit Delay?

Edi Sukarmanto, Magnaz Lestira Oktaroza, Karina Nur Astari

Pengaruh Sistem Pengendalian Intern Pemerintah Dan Ketersediaan Anggaran Terhadap Efektivitas Penerapan Sistem Informasi Keuangan Daerah Pada Pemerintah Provinsi Dan Kabupaten/Kota Se-Sumatera Utara.

Eka Nurmala Sari, Muhyarsyah, Nunung Sri Wahyuni

Pengaruh Rasio Solvabilitas Terhadap Kondisi Financial Distress Nurhayati, Muhammad Kevin Aprilio

Implikasi Keunggulan Bersaing Terhadap Kinerja Organisasi Pada Sektor Industri Manufaktur Kimia di Provinsi Banten.

Uli Wildan Nuryanto, Masyhudzulhak Djamil MZ, Achmad Hidayat Sutawidjaya,

Ahmad Badawi Saluy

Pengaruh Kinerja ICSR Terhadap Readability ICSR Menggunakan Gunning Fog Dan Flesch-Kincaid Indeks Dengan Size, Kinerja Keuangan, Leverage Dan Growth Sebagai Variabel Kontrol

Riyang Mardini

Dampak Covid-19 Terhadap Harga Saham Dan Kinerja Keuangan Perusahaan. Annisa Nadiyah Rahmani.

Pengaruh Pengungkapan Corporate Social Responsibility Dan Mekanisme Good Corporate Governance Terhadap Tax Avoidance.

Diamonalisa Sofianty, Lena Herlina I 


\title{
IMPLIKASI KEUNGGULAN BERSAING TERHADAP KINERJA ORGANISASI PADA SEKTOR INDUSTRI MANUFAKTUR KIMIA DI PROVINSI BANTEN
}

\author{
Uli Wildan Nuryanto \\ Doctoral Postgraduate Program \\ Mercu Buana University \\ uli.wildan11@gmail.com \\ Achmad Hidayat Sutawidjaya \\ Doctoral Postgraduate Program \\ Mercu Buana University \\ ahsuta69@gmail.com
}

\author{
Masyhudzulhak Djamil MZ \\ Doctoral Postgraduate Program \\ Mercu Buana University \\ masydk@gmail.com
Ahmad Badawi Saluy
Doctoral Postgraduate Program
Mercu Buana University badawi_saluy@yahoo.co.id

\begin{abstract}
In current dynamic business environment, the competition is getting stiffer and performance organizational becomes issue, the caracteristics that occurred in the industrial revolution 4.0. This condition requires organizations to increase the performance to be sustain. Competence and knowledge management as internal resources that reffer to $R B V$ are strengths hat are very important as predictors in improving performance. For this reason, the study has explored the indicators of each of the predictors and also test the relationships between latent variable that have been hypothesized. This research focus to the industrial chemical manufactur at Banten Province Indonesia which is become the province with the third largest number of chemical firms in Indonesia. Regarding to the central bureau statistics of Indonesia, the values of productivity and human resources capability from downstream chemical manufactur sector below the target. This research using SEM-PLS method to measure 97 respondents from the level supervisor and manajerial. The final results provide a positive and significant relationship between competence and knowledge management through competitive advantage and organizatioan performance. Competitive advantage also increasse the relationship between competence and knowledge management through the organizational performance. This result has implication for managerial levels to increase human resources performance so it can improve the firm competitive advantage.
\end{abstract}

Keywords: Kompetensi, Competence, Knowledge Management, Competitive Advantage, Organizational Performance, Chemical manufacturer sector.

\begin{abstract}
Abstrak
Dalam lingkungan bisnis yang dinamis saat ini, persaingan semakin ketat dan kinerja organisasi menjadi isu, ciri khas yang terjadi pada revolusi industri 4.0. Kondisi ini menuntut organisasi untuk meningkatkan kinerja agar bisa berkelanjutan. Manajemen
\end{abstract}


kompetensi dan pengetahuan sebagai sumber daya internal yang mengacu pada RBV merupakan kekuatan yang sangat penting sebagai prediktor dalam meningkatkan kinerja. Untuk itu, penelitian ini mengeksplorasi indikator dari masing-masing prediktor dan juga menguji hubungan antar variabel laten yang telah dihipotesiskan. Fokus penelitian ini adalah pada industri manufaktur kimia di Provinsi Banten Indonesia yang menjadi provinsi dengan jumlah perusahaan kimia terbesar ketiga di Indonesia. Terkait dengan Badan Pusat Statistik Indonesia, nilai produktivitas dan kemampuan sumber daya manusia dari sektor hilir manufaktur kimia di bawah target. Penelitian ini menggunakan metode SEM-PLS dengan mengukur 97 responden dari tingkat supervisor dan manajerial. Hasil akhir memberikan hubungan yang positif dan signifikan antara kompetensi dan manajemen pengetahuan melalui keunggulan kompetitif dan kinerja organisasi. Keunggulan kompetitif juga meningkatkan hubungan antara kompetensi dan manajemen pengetahuan melalui kinerja organisasi. Hasil ini berimplikasi pada level manajerial untuk meningkatkan kinerja sumber daya manusia sehingga dapat meningkatkan keunggulan bersaing perusahaan.

\section{Kata Kunci: Kompetensi, Kompetensi, Knowledge Management, Keunggulan Kompetitif, Kinerja Organisasi, Sektor Manufaktur Bahan Kimia.}

\section{PENDAHULUAN}

Pasar yang semakin kompetitif dan kesadaran konsumen akan kualitas produk yang dibeli dengan biaya yang bersaing, serta trend produk yang berubah-rubah sesuai dengan tuntutan pelanggan telah merubah bisnis industri menjadi lebih dinamis (Ko, 2015). Persaingan ini berawal pada tahun 1990 ketika pasar semakin intensif untuk mendapatkan produk yang tepat dan pelayanan ke tempat mereka dengan waktu yang cepat dan berbiaya rendah ( $\mathrm{Li}$ et all, 2006). Hal ini menimbulkan dampak dan permasalahan khususnya bagi perusahaan yang terbiasa menyusun strategi bisnisnya dengan mengandalkan kemampuan untuk memprediksi trend lima tahun hingga sepuluh tahun kedepan untuk merubah kebiasaannya dengan melakukan perubahan dan inovasi yang cepat (Munir, 2011). Untuk dapat mempertahankan eksistensinya, maka banyak perusahaan yang melakukan berbagai macam cara untuk melakukan perubahan sesuai dengan tuntutan dari pelanggan seperti misalnya memperluas pangsa pasar (Hertati., 2015), melakukan inovasi terkait produk dan layanan yang diberikan kepada pelanggan (Hertati, 2015), memperbaiki system produksi, melakukan peningkatan terhadap system organisasi serta melakukan penghematan biaya (Hertati, 2016). Organisasi yang tidak mampu mengikuti perubahan lingkungan akan sangat sulit untuk dapat bersaing di dalam 
persaingan ini sehingga mau tidak mau organisasi harus dapat menciptakan keunggulan bersaing agar bisnisnya mampu bertahan (Kusuma dan Devie, 2013).

Hasil penelitian Hertati,(2016) menyatakan bahwa keunggulan bersaing merupakan suatu keuntungan lebih dari pesaingnya yang dapat diperoleh melalui menawarkan nilai konsumen yang lebih besar, dengan harga yang lebih rendah ataupun memberikan keuntungan yang lebih besar kepada pelanggan dan memberikan pelayanan yang mampu memberikan nilai lebih kepada pelanggan (Porter, 1985). Keunggulan bersaing juga didefiniskan sebagai kemampuan sebuah organisasi untuk melakukan posisi bertahan dari pesaingnya (Li et al, 2006) dengan indikatornya masing-masing adalah harga, kualitas, delivery, dependability, inovasi produk, dan time to market. Hal tersebut sejalan dengan rumusan keunggulan bersaing yang diajukan oleh Porter (1985) bagi perusahaan yaitu biaya rendah atau diferensiasi produk. Dalam jangka waktu 4 tahun terakhir terjadi penurunan pertumbuhan yang sangat signifikan dalam sektor inustri manufaktur kimia yang ada di Indonesia dimana nilai pertumbuhan ekonomi sektor tersebut masih berada di bawah pertumbuhan ekonomi nasional. Penurunan ini terjadi pada sub sektor industri kimia dan barang dari bahan kimia yang merupakan downstream industri manufkatur kimia. Nilai produktivitas dan kemampuan SDM sektor downstream masih berada dibawah nilai rata-rata sektor non migas dimana besarnya nilai rata-rata produktivitas dan kemampuan SDM sektor non migas dalam 5 tahun terakhir berada pada nilai 398.5 Juta/Orang sedangkan nilai rata-rata produktivitas dan kemampuan SDM sektor industri manufaktur kimia downstream sebesar 336,8 Juta/orang pada tahun 2017. Hal tersebut berbeda dengan sub sektor industri manufaktur kimia Upstream yang memiliki nilai produktivitas dan kemampuan SDM sebesar 1.211,9 Juta/orang pada tahun 2017.

Penelitian Hertati (2019) mengungkapkan bahwa peningkatan keunggulan bersaing yang ada akan didapatkan apabila didukung oleh potensi SDM yang unggul dan berkualitas tinggi guna mendukung perusahaan dalam mencapai sasaran mutu yang telah ditentukan. Namun sayangnya dalam pemenuhan kebutuhan SDM sendiri terdapat kendala yang cukup mengganjal bagi industri saat ini. Berdasrkan hasil Focus Group Discussion (FDG) antara key person pengusaha industri manufaktur, didapatkan persoalan terkait dengan kesenjangan keterampilan (skill gap) terutama pada SDM tingkat menengah serta kekurangan pasokan dan ketidaksesuaian keterampilan 
(skill mismatch) pada level SDM tenaga ahli. Hal inilah yang menjadkan posisi industri dalam negeri sulit untuk melakukan inovasi dan pengembangan sehingga berdasarkan hasil laporan Global Innovation Index tahun 2017 posisi dalam negeri menduduki posisi ke 87 dari 137 negara dalam hal inovasi. Hal ini menggambarkan rentannya kemampuan industri untuk dapat melakukan pengembangan teknologi guna menghasilkan kemampuan daya saing yang tinggi. Untuk itulah perlunya sutau peningkatan SDM yang berbasiskan kompetensi untuk dapat meningkatkan keunggulan bersaing sehingga dapat mendukung terhadap peningkatan kinerja perusahaan.

Penelitian Hertati (2019) menyatakan bahwa selain persiangan bebas, potensi yang menjadi ancaman namun juga dapat menjadi peluang pada sektor industri manufaktur kimia adalah perkembangan ilmu pengetahuan dan teknologi yang telah menggeser revolusi industri ketiga menjadi revolusi industri 4.0 yang memiliki pola disruptif teknologi yang hadir sangat cepat dan mengancam perusahaan-perusahaan incumbent. Disisi lain dengan perkembangan teknologi justru dapat dijadikan sebagai pelung bagi sektor manufaktur industri dengan penggunaan teknologi automatisasi menggantikan sistem yang manual. Penelitan Hertati (2016) menyatakan bahwa semakin cepatnya arus informasi akibat kemajuan teknologi akan membantu perusahaan untuk mendapatkan arus informasi dengan cepat dan biaya yang rendah. Namun kembali kepada sejauh mana tingkat SDM dalam menguasi kompetensi dan manajemen pengetahuan yang ada untuk beradaptasi sehingga dapat menguasai teknologi terbaharukan bahkan mampu melakukan inovasi bagi perusahaan. Untuk itulah penelitian ini berusaha menggali informasi yang ada terkait dengan pengaruh kompetensi dan bagaimana manajemen pengetahuan berperan terhadap peningkatan keunggulan bersaing perusahaan guna meningkatkan kinerja organisasi.

\section{LANDASAN TEORI}

\subsection{Sektor Industri Manufaktur Kimia}

Sektor manufaktur masih menjadi kontributor terbesar terhadap Produk Domestik Bruto (PDB) nasional dengan pencapaian 20,16\% pada tahun 2017. Sedangkan kontributor terbesar PDB selanjutanya adalah sektor pertanian, kehutanan dan perikanan sebesar $13,14 \%$, sektor perdagangan sebesar $13,01 \%$, sektor konstruksi sebesar $10,38 \%$ dan sektor pertambangan sebesar 7,57\%. 
Klasifikasi industri yang digunakan dalam survey industri pengolahan adalah klasifikasi yang berdasar kepada Standard Industrial Classification of All Economic Activities (ISIC) revisi ke 4 yang telah disesuaikan dengan kondisi di Indonesia dengan nama Klasifikasi Baku Lapangan Usaha Indonesia (KBLI) tahun 2009. Lebih lanjut golongan pokok KBLI terbagi menjadi 24 sub sektor industri dimana industri kimia masuk kedalam klasifikasi ke 11 yang disebut dengan industri bahan kimia dan barang dari bahan kimia. Dalam 5 tahun terakhir, sektor industri manufaktur kimia mampu menghasilkan rata-rata ekspor per tahun sebesar 10,83 miliar US\$ dan mampu menyerap lapangan pekerjaan sebanyak 284.887 angkatan kerja produktif dengan jumlah perusahaan sebanyak 1.376 yang tersebar di 22 provinsi di Indonesia. dari 22 provinsi tersebut terdapat 3 provinsi yang memiliki jumlah perusahaan kimia terbanyak diantaranya adalah provinsi Jawa Barat dengan 388 perusahaan, provinsi Jawa Timur dengan 333 perusahaan dan provinsi Banten dengan 292 perusahaan.

Emillia (2015) menyatakan bahwa sektor manufaktur termasuk industri kimia didalamanya merupakan landasan berkembangnya ekonomi nasional dan sektor penting bagi pertumbuhan ekonomi yang berkelanjutan dan produktif. Perkembangan industri kimia di Indonesia juga tidak dapat dipisahkan dari kemampuan daya saing industri itu sendiri, berdasarkan data The International Institute for Management Development (IMD) daya saing industri manufaktur Indonesia dalam 11 tahun terakhir berada pada posisi yang tidak begitu baik yaitu di peringkat 40 dari 193 negara yang terdaftar di UN. Hal inilah yang menjadi daya tarik bagi peneliti untuk melakukan penelitian lebih mendalam terkait keunggulan bersaing dan kinerja organisasi pada sektor industri manufaktur kimia.

\subsection{Kinerja Organisasi}

Definisi kinerja digunakan pada berbagai disiplin ilmu serta bergantung kepada bidang organisasi itu sendiri (Jenatabadi, 2015). Kinerja dapat disefinisikan sebagai sebuah pencapaian hasil yang dapat dilihat dari tingkatan sejauh mana organisasi dapat mencapai tujuan yang didasarkan pada tujuan yang sudah ditetapkan sebelumnya. Kinerja merupakan hasil dari kegiatan kerjasama diantara anggota atau komponen organisasi dalam rangka mewujudkan tujuan organisasi. Dalam kerangka organisasi terdapat hubungan antara kinerja perorangan dengan kinerja organisasi. Organisasi dalam 
mencapai tujuan yang telah ditetapkan harus melalui kegiatan-kegiatan yang digerakan oleh orang atau sekelompok orang yang aktif berperan sebagai pelaku, dengan kata lain tercapainya tujuan organisasi hanya dimungkinkan karena adanya upaya yang dilakukan oleh orang dalam organisasi tersebut. Friedlander dan Pickle (1968) menganggap kinerja sebagai variabel yang yang dapat mengukur keberhasilan perusahaannya dan juga mengukur sejauh mana kemampuan perusahaan mencapai targetnya yang diukur melalui efisiensi, efektifitas dan lainnya bergantung kepada konteks organisasi. Efektifitas mengacu kepada sejauh mana fungsi produksi untuk dapat memenuhi tuntutan dan persyaratan dari stakeholder seperti pelanggan, top manajemen dan pemegang saham. Sedangkan efisiensi adalah bagaimana sumber daya organisasi secara ekonomi dimanfaatkan melalui pencapaian fungsi untuk mencapai tujuannya. MacLeod et al (2007) menyatakan bahwa kuantitatif target kinerja adalah satu-satunya cara untuk menjadikannya bernilai, selanjutnya kinerja dapat mengacu kepada sifat dan kualitas tindakan yang dilakukan dalam suatu perusahaan untuk mencapai pencapaian dalam fungsi atau tugas utamanya untuk menghasilkan laba.

Dalam penelitian ini kinerja organisasi menggunakan empat dimensi yang telah disesuaikan dengan kondisi tempat penelitian, diantaranya adalah kinerja terhadap komitemen organisasi, kinerja ekonomi, kinerja lingkungan dan kinerja sosial yang mengacu kepada hasil penelitian Cantele dan Zardini (2018), Iuliana dan Criveanu (2016) serta Morin dan Audebrand (2014). Dengan indikatornya yaitu komitmen karyawan terhadap perusahaan dan komitmen karyawan untuk mengutamakan kepentingan perusahaan diatas kepentingan individu (OP1), produktivitas (OP2), efisiensi (OP3), pencegahan dan pengurangan polusi dan memastikan keamanan produk (OP4) serta perlakuan yang sama terhadap semua karyawan (OP5).

\subsection{Keunggulan Bersaing}

Keunggulan bersaing merupakan suatu potensi kekuatan dalam persaingan yang ditentukan oleh tindakan-tindakan manajerial seperti inovasi sumber daya yang dihasilkan maupun posisi strategis yang dimiliki organisasi. Keunggulan bersaing merupakan alat dalam pencapaian tujuan-tujuan organisasi untukmendapatkan keberhasilan melebihi para pesaingnya (Sulistyandari dan Handayani, 2011). Hameed (2009) berpendapat bahwa perusahaan yang berhasil dapat dilihat dari kemampuannya 
untuk menghasilkan penjualan, laba, dan market share. Keunggulan bersaing perusahaan berasal dari dua sumber yaitu lingkungan internal dan eksternal perusahaan meliputi, sumber daya manusia, modal, pemasuk, supplier, pelanggan dan mitra kerja. Pemikiran awal mengenai keunggulan bersaing tidak dapat dilepaskan dari Ansoff (1965) yang menyatakan bahwa keunggulan bersaing merupakan fungsi identifikasi dimensi produk pasar yang tepat bagi posisioning perusahaan. Demikian juga halnya dengan Porter (1985), yang menyatakan bahwa keunggulan bersaing merupakan upaya penciptaan nilai pelanggan yang lebih baik dibandingkan dengan pesaingnya dengan cara melakukan aktivitas-aktivitas spesifik secara ekonomis ataupun kualitas pelayanan yang superior ataupun kombinasi keduanya dibandingkan dengan kompetitornya.Keunggulan bersaing dapat juga berasal dari sumber daya yang dimiliki perusahaan yang dikenal dengan perspektif Resources Based View (RBV) atau perspektif berbasis sumber daya yang dikenalkan oleh Penrose (1959). Menurutnya keunggulan bersaing dapat dicapai dengan menciptakan skala ekonomis, meningkatkan kapabilitas manajemen dan kapasitas teknologi. Konsep ini kemudian didefinisikan ulang oleh Barney (1991) yang menjelaskan bahwa karakteristik sumber daya yang bernilai bagi keunggulan bersaing adalah yang berkaitan dengan sumber daya yang bernilai, kompleks, eksklusif, mudah digeneralisasi dan susah ditiru oleh pesaingnya. Pada perspektif tersebut keunggulan bersaing strategis diperoleh dari sumber daya inti dan kompetensi inti yang bernilai, langka, susah ditiru, dan tidak ada penggantinya.

Penelitian ini menggunakan dimensi keunggulan bersaing dari perspektif RBV kedalam empat dimensi antara lain sumber daya yang bernilai, sumber daya yang langka, sumber daya yang tidak ada bandingan dan sumber daya yang tidak tergantikan. Dengan jumlah indikator sebanyak tujuh indikator yang mengacu kepada kondisi tempat penelitian dan juga hasil penelitian seperti Li dan Liu (2018), Ding et al (2018), Gautam dan Ghimiee (2016), Stefanikova dan Masarova (2014) serta Awaad (2014). Dengan indikatornya yaitu komitmen dan kemampuan untuk memberikan kepuasan kepada pelanggan (CA1), kemampuan berinovasi (CA2), kemampuan bertahan menghadapi risiko (CA3), penggunaan teknologi(CA4), komitmen untuk mencapai tujuan dengan biaya berapapun (CA5). 


\section{$2.4 \quad$ Kompetensi}

Terkait dengan RBV, kompetensi merupakan suatu modal yang berasal dari internal organisasi dan memiliki nilai bagi organisasi untuk dapat menghasilkan keunggulan bersaing. Dalam suatu perusahaan, kompetensi inti merupakan mutlak sebagai kekuatan yang mendasari perusahaan dalam beroperasi, sedangkan kaitannya dengan keunggulan bersaing maka peneliti juga menggunakan kompetensi pembeda sebagai bentuk dimensi dari kompetensi. Sedangkan untuk professional kompetensi peneliti juga menggunakannya sebagai suatu dimensi dan prediktor terhadap keunggulan bersaing dan kinerja organisasi, sehingga diharapkan dapat mewakili dari adanya keberagaman makna terkait dengan kompetensi. Otoo dan Mishra (2018) mendefinisikan kompetensi sebagai sekelompok pengetahuan, keterampilan, kualitas pribadi dan pengalaman, sedangkan Hellrigel dan Slocum (2011) mendefinisikan kompetensi kedalam dimensi kompetensi etis karyawan, kompetensi diri, kompetensi keragaman, kompetensi lintas budaya, kompetensi komunikasi, kompetensi tim dan mengubah kompetensi sebagai tujuh kompetensi utama yang mempengaruhi kompetensi individu, tim dan efektivitas organisasi.

Perusahaan melakukan berbagai macam usaha untuk dapat memiliki keunggulan bersaing sebagai senjata yang ampuh dalam meningkatkan kinerja organisasinya, salah satunya adalah dengan memperhitungkan dan menggunakan kompetensi inti sebagai suatu kekuatan internal yang dapat menghasilkan nilai lebih, diferensiasi yang kuat (Hamel dan Prahalad, 1994). Telah banyak penelitian dari akademisi yang mendapatkan suatu kesimpulan bahwa kompetensi inti merupakan kekuatan yang sangat fital bagi organisasi sebagai alat untuk mendapatakan keunggulan bersaing (Hafeez dan Abdelmeguid, 2003).

Srivastava (2005), kompetensi inti merupakan dasar dari semua sumber daya internal yang dapat dijadikan sebaga keunggulan bersaing. Banerjee (2003), kompetensi inti sebagai segala sesuatu yang merupakan informasi dan pengetahuan tentang keberhasilan atau kegagalan dalam menggunakan sumber pengetahuan. Chen and Wu (2007), kompetensi inti sebagai kemampuan untuk beroperasi secara efisien di dalam lingkungan bisnis dalam rangka menanggapi tantangan yang ada. Leonard dan Barton (2000), kompetensi inti sebagai kompetensi yang membedakan perusahaan dari lingkungannya. Sedangkan menurut Sanchez dan Heene (1997) yang dimaksud dengan 
kompetensi inti adalah hasil dari proses pembelajaran kolektif yang dimanifestasikan kedalam kegiatan dan proses bisnis. Kompetensi professional menurut McCelland (1973) didefinisikan sebagai kemampuan yang dibutuhkan ditempat kerja yang berhubungan dengan kapasitas pribadi seseorang yang berhubungan dengan kinerja seseorang dalam melakukan pekerjaannya. Kompetensi professional mengacu kepada ketepatan, keterampilan dan perilaku teladan, sehingga karyawan harus memperkuat aspek-aspek professional kompetensi agar kompeten dalam menjalankan tugasnya (Mansfield, 1978). Lysaght dan Altschuld (2001), inti dari kompetensi professional adalah pengetahuan, keterampilan, standar, kompetensi dan identifikasi.Kompetensi pembeda adalah kemampuan, aktivitas dan kapasitas yang bersifat unik dibandingkan dengan pesaingnya (Stoner, 1987). Menghasilkan produk dengan kualitas yang lebih tinggi, melakukan inovasi, memiliki pengetahuan dan kemampuan ditempat kerja, atau kemampuan merespon dengan cepat terhadap permintaan pelanggan dibandingkan dengan pelanggan. Tsou et al (2014); Garcia dan Velasco (2008), kompetensi pembeda kemampuan untuk dapat melakukan inovasi yang menghasilkan metode atau materi baru dengan menggunakan teknologi serta meningalkan metode sebelumnya

Penelitian ini menggunakan kompetensi inti sebagai dimensi dengan tiga indikator utama yang mengacu kepada hasil penelitian dari Otoo dan Mishra (2018) serta Agha et al (2012), ketiga indikator tersebut adalah kompetensi dalam berkomunikasi (COM1), kompetensi dalam beretika (COM2) dan kompetensi untuk bekerja sama (COM3). Sedangkan professional kompetensi menggunakan dua indikator antara lain kognitis atau pemahaman akan material atau bahan (COM4), dan kemampuan untuk mengoperasikan fasilitas yang ada (COM5) yang mengacu kepada penelitian Ko (2015). Sedangakan untuk kompetensi pembeda peneliti menggunakan satu indikator yaitu kompetensi untuk melakukan inovasi (COM6) yang mengacu kepada penelitian Tsou et al (2014).

\subsection{Manajemen Pengetahuan}

Manajemen pengetahuan merupakan formalisasi dan akses ke pengalaman, pengetahuan, dan keahlian yang menciptakan kemampuan baru yang memungkinkan kinerja yang unggul, mendorong inovasi dan meningkatkan nilai pelanggan (Khan, 2012). Manajemen pengetahuan sebagai sebuah proses yang membantu organisasi untuk 
menemukan, memilih, mengatur, menyebarkan dan mentransfer informasi penting dan keahlian yang diperlukan untuk kegiatan organisasi (Zaied et al, 2012).

Perusahaan yang efeltif dalam memperoleh pengetahuan akan mampu menciptakan dan mempertahankan keunggulan bersaing dalam ekonomi berbasis pengetahuan. Sementara perusahaan lainnya yang tidak mampu memperoleh dan menciptakan pengetahuan akan mengalami kesulitan dalam mempertahankan posisi bersaing mereka (Deed dan Hill, 1996 dalam Khan 2012). Pengetahuan merupakan sumber penting dari keunggulan bersaing yang tersedia untuk sebuah organisasi diabad kedua puluh satu (McFadyen dan Canella, 2004).

Abad kedua puluh satu merupakan era pengetahuan ekonomi, dimana sebagian besar organisasi memiliki pengetahuan yang memungkinkan mereka untuk meningkatkan kinerja organisasinya (Zaied et al, 2012). Dalam dunia persaingan yang sangat agresif seperti sekarang ini, manajemen pengetahuan menjadi kendaraan utama bagi organisasi untuk mencapai tujuan mereka dan untuk bersaing dengan baik. Manajemen pengetahuan diakui sebagai senjata penting untuk mempertahankan keunggulan bersaing dan meningkatkan kinerja (Zaied et al, 2012).

Melalui manajemen pengetahuan, organisasi mengidentifikasikan pengetahuanpengetahuan yang dimiliki dan memanfaatkannya untuk meningkatkan kinerja dan menghasilkan berbagai inovasi (Munir, 2011). Organisasi harus menyadari pentingnya manajemen pengetahuan yang efektif, karena biaya mengabaikannya sangat besar (Ling et al, 2008). Sehingga evaluasi manajemen pengetahuan menjadi penting karena menyediakan referensi untuk mengarahkan organisasi dalam meningkatkan keunggulan bersaing sehingga mampu menciptakan kinerja organisasi yang baik. Dimensi manajemen pengetahuan pada penelitian ini di identifikasikan menjadi lima tahapan seleksi pengetahuan yang telah disesuaikan dengan tempat penelitian dan mengacu kepada penelitian Mahdi et al (2018), Turulja dan Bajgoric (2018), Cahyaningsih et al (2017), Mahdavi dan Pirzad (2017), Al-Refaie dan Al-Tahar (2016), Hazen (2015) ke dalam proses identifikasi pengetahuan, penciptaan pengetahuan, penyimpanan pengetahuan, berbagi pengetahuan dan penggunaan pengetahuan. Dengan jumlah indikator penelitian sebanyak enam indikator yaitu pendataan terhadap potensi pengetahuan (KM1), mengkonversi dan memformalkan pengetahuan menjadi standar acuan (KM2), proteksi terhadap pengetahuan (KM3), transfer pengetahuan (KM4), 
berbagi pengetahuan (KM5) dan penggunaan pengetahuan kedalam kegiatan rutin operasional (KM6).

Penelitian ini mengintegrasikan antara teori resources based view (RBV) dan knowledge based teori (KBV), sehingga peneliti menamakan konsep keterbaruan pada penelitian ini sebagai Gain Competitive Advantage for reliable Industry, penelitian ini juga mengembangkan beberapa hipotesis untuk mengekstensi model yang ada sebelumnya menjadi model baru.

\section{METODE PENELITIAN}

\subsection{Conceptual Framework}

Penelitian ini di desain untuk menjawab permasalahan yang telah diformulasikan melalui hipoteis. Desain yang dibuaut oleh Kerlinger (2000) adalah struktur penyelidikan yang disusun sedemikian rupa untuk membantu para peneliti mendapatkan jawaban yang pasti. dengan menggunakan pendekatan deduktif yang terdiri dari penelitian eksplorasi untuk menemukan beberapa hubungan yang relative baru dan penjelasan mendetail. Dengan menerapkan pendekatan deduktif peneliti berusaha untuk melihat data secara empiris dan sistematis yang kemudian dibandingkan dengan teori yang ada. Studi kausal berusaha untuk menjelaskan hubungan pengaruh kompetensi, manajemen pengetahuan, keunggulan bersaing terhadap kinerja organisasi pada sektor industri manufaktur kimia. Kerangka Konsep yang diajukan oleh peneliti adalah sebagai berikut:

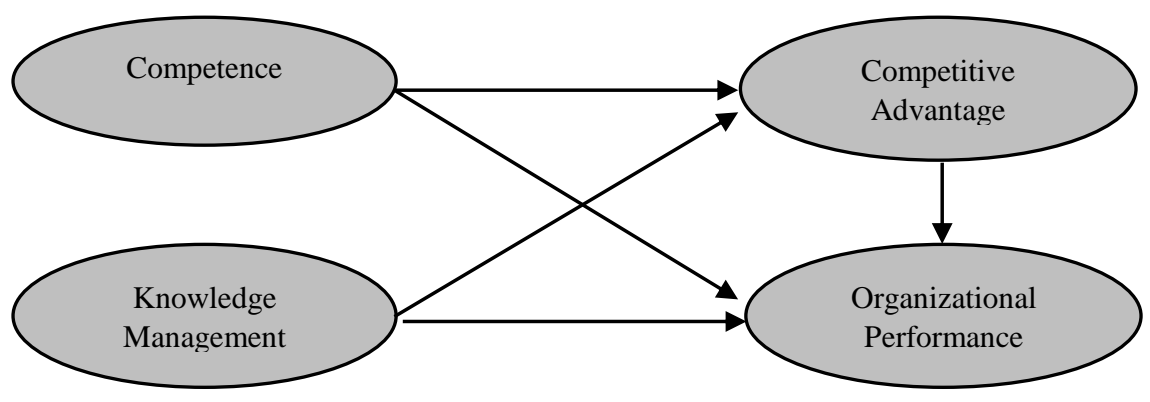

Gambar 1. Framework Penelitian

\subsection{Population and Sample}

Penelitian ini dilakukan terhadap perusahaan kimia di provinsi Banten yang yang tersebar di Kabupaten Serang, Kota Cilegon dan Kabupaten Tangerang dengan melibatkan 97 responden. Teknik pengambilan sample dengan menggunakan teknik 
purposive sampling dan unit analisis dilakukan pengukuran kepada karyawan level manajerial sebagai sebagai pengambil kebijakan pada perusahaannya masing-masing dengan masa kerja minimal satu tahun.

\subsection{Classification of Variables Research}

Variabel dalam penelitian ini dikelompokan kedalam tiga kelompok, pertama variabel eksogen yaitu kompetensi dan manajemen pengetahuan, kedua adalah variabel intervening yaitu keunggulan bersaing dan terakhir adalah variabel endogen yaitu kinerja organisasi. Penelitian ini menggunakan kuesioner dengan skala Likert dengan nilai 1-5 dimana skala 1 menyatakan sangat tidak setuju, skala 2 tidak setuju, skala 3 netral, skala 4 setuju dan skala 5 sangat setuju.

\subsection{Model Analysis}

Penelitian ini bertujuan untuk mendapatkan model terbaik dalam menjelaskan pengaruh kompetensi, manajemen pengetahuan dan keunggulan bersaing terhadap kinerja organisasi pada sektor industri manufaktur kimia. Sedangkan indikator yang digunakan adalah yang mengacu kepada penelitian terdahulu dan berhubungan dengan tempat penelitian ini. Teknik analisis data menggunakan SEM PLS, menurut Ferdinand (2002) SEM sangat cocok untuk mengkonfirmasi berbagai macam konstruk yang ada terhadap variabel laten. Menguji kompatibilitas atau akurasi model berdasarkan data empiris yang diamati. Menguji hubungan sebab akibat antara faktor-faktor yang diamati dalam model.

\subsection{Hypothesis}

Berdasarkan hasil kajian literatur mendalam terhadap masing-masing hubungan antar variabel, didapatkan hubungan dan pengaruh sebagai berikut:

\subsubsection{Hubungan kompetensi terhadap keunggulan bersaing}

Hasil penelitian sebelumnya menunjukan kompetensi dan kualitas berpengaruh signifikan terhadap keunggulan bersaing pada perusahaan kecil dan sedang (Ismail et al, 2014). Sedangkan hasil penelitian Adiputra dan Mandala (2017) menunjukan bahwa kompetensi dan kapabilitas berpengaruh positef da terhadap kinerja perusahaan, namun kompetensi tidak berpengaruh signifikan sedangkan kapabilitas berpengaruh signifikan. Agha et al (2012), Jamhour dan Agha (2010) dan Hastjarjo, et al (2016) menunjukan bahwa kompetensi berpengaruh signifikan terhadap kemampuan bersaing dan 
keunggulan bersaing serta dapat meningkatkan kinerja organisasi. Berdasarkan penelitian-penelitian yang telah dilakukan diatas terkait dengan hubungan antara kompetensi dengan keunggulan bersaing, maka peneliti mengambil kesimpulan sementara sebagai berikut:

HI: Kompetensi berpengaruh signifikan terhadap keunggulan bersaing pada sektor industri manufaktur kimia

\subsubsection{Hubungan manajemen pengetahuan terhadap keunggulan bersaing}

Hasil penelitian terkait hubungan antara manajemen pengetahuan terhadap keunggulan bersaing didapatkan bahwa terdapat hubungan yang signifikan antara manajemen pengetahuan terhadap keunggulan bersaing (Mahdi et al, 2018). Sedangkan hasil penelitian Kusuma dan Devie (2013) menunjukan bahwa manajemen pengetahuan memiliki pengaruh positif dan signifikan terhadap keunggulan bersaing dan juga kinerja organisasi. Nazarpour dan Shirin (2017) Proses sumber daya manusia memiliki pengaruh positif dan signifikan terhadap manajemen pengetahuan dan keunggulan bersaing, sama halnya dengan manajemen pengetahuan yang memiliki pengaruh signifikan terhadap keunggulan bersaing dimana pengukuran keunggulan bersaing melalui pendekatan VRIO. Almasi dan Pirzad (2017) menyimpulkan bahwa modal intelektual berpengaruh signifikan terhadap menajamen pengetahuan dan keunggulan bersaing, namun manajemen pengetahuan tidak berpengaruh signifikan terhadap keunggulan bersaing, sedangkan Lee et al (2016) menyimpulkan bahwa manajemen pengetahuan memiliki pengaruh yang signifikan terhadap inovasi teknologi dan keunggulan bersaing dan inovasi teknologi memiliki pengaruh yang signifikan terhadap keunggulan bersaing. Berdasarkan penelitian-penelitian yang telah dilakukan diatas terkait dengan hubungan antara manajemen pengetahuan dengan keunggulan bersaing, maka peneliti mengambil kesimpulan sementara sebagai berikut:

H2: Manajemen Pengetahuan berpengaruh signifikan terhadap keunggulan bersaing pada sektor industri manufaktur kimia.

\subsubsection{Hubungan keunggulan bersaing terhadap kinerja organisasi}

Penelitian sebelumnya yang membahas hubungan terkait antara keunggulan bersaing terhadap kinerja organisasi seperti Cantele dan Zardini (2018) dmenyimpulkan bahwa terdapat pengaruh yang signifikan terhadap dimensi keberlangsungan perusahaan jangka penajang terhadap keunggulan bersaing serta pengaruh yang signifikan terhadap 
keunggulan bersaing dan kinerja perusahaan. Lorenzo et al (2017) menyimpulkan bahwa keunggulan bersaing berpengaruh signifikan terhadap kinerja perusahaan minuman di Spanyol, hal ini senada dengan penelitian Othman et al (2015), Kusuman dan Devie (2013) dan Gyampah dan Acquaah (2008) dimana penelitiannya juga menekankan bahwa sumber daya perusahaan yang ada dan berasal dari internal perusahaan akan sangat menentukan keunggulan bersaing perusahaan. Berdasarkan penelitian-penelitian yang telah dilakukan diatas terkait dengan hubungan antara manajemen pengetahuan dengan keunggulan bersaing, maka peneliti mengambil kesimpulan sementara sebagai berikut:

H3: Keunggulan bersaing berpengaruh signifikan terhadap kinerja organisasi pada sektor industri manufaktur kimia

\subsubsection{Hubungan kompetensi terhadap kinerja organisasi}

Penelitian sebelumnya yang menguji hubungan antara kompetensi terhadap kinerja organisasi diantaranya adalah Otoo dan Mishra (2018) yang menyimpulkan bahwa sumber daya manusia yang baik akan meningkatkan kompetensi karyawan dan dampaknya akan berpengaruh signifikan terhadap kinerja organisasi, sedangkan Nimsith et al (2016), Agha et al (2012), Jamhour dan Agha (2010) dan Hastjarjo et al (2016) menyimpulkan bahwa kemampuan dinamis organisasi terhadap risiko lingkungan yang ada dan juga kompetensi berpengaruh signifikan terhadap kinerja organisasi. Sehinggadapat disimpulkan bahwasanya kompetensi merupakan sumber daya internal yang sangat berharga bagi perusahaan untuk dapat meningkatkan kinerja organisasinya. Berdasarkan penelitian-penelitian yang telah dilakukan diatas terkait dengan hubungan antara kompetensi dengan kinerja organisasi, maka peneliti mengambil kesimpulan sementara sebagai berikut:

H4: Kompetensi berpengaruh signifikan terhadap kinerja organisasi pada sektor industri manufaktur kimia

\subsubsection{Hubungan manajemen pengetahuan terhadap kinerja organisasi}

Pengaruh antara manajemen pengetahuan terhadap kinerja organisasi didapatkan kesimpulan bahwa terdapat hubungan positif dan signifikan, hal ini senada dengan hasil penelitian Almudallal (2015), namun dalam penelitiannya ia mendapatkan besarnya pengaruh yang sangat tinggi yaitu sebesar 70\%. Manajemen pengetauan yang ditunjang dengan aplikasi informasi teknologi juga akan berpengaruh signifikan terhadap kinerja perusahaan (Lopez dan Alegree, 2011). Sedangkan Nowacki dan Bachnick (2015) 
menyimpulkan bahwa terdapat pengaruh yang signifikan anatara manajemen pengetahuan terhadap efektifias perusahaan yang dilihat dari sisi kemampuan berinovasi, pendapatan perusahaan, kemampuan daya saing. Sedangkan Muthuveloo et al (2017) menyatakan bahwa terdapat pengaruh yang signifikan terhadap dimensi manajemen pengetahuan yaitu sosialisasi dan internalisasi terhadap kinerja perusahaan. Berdasarkan penelitian-penelitian yang telah dilakukan diatas terkait dengan hubungan antara manajemen pengetahuan terhadap kinerja organisasi, maka peneliti mengambil kesimpulan sementara sebagai berikut:

H5: Manajemen pengetahuan berpengaruh signifikan terhadap kinerja organisasi pada sektor industri manufaktur kimia.

\section{HASIL DAN PEMBAHASAN}

\subsection{Hasil Uji Deskriptif}

Tabel 1

Demographic Respondents

\begin{tabular}{|c|c|c|}
\hline Profile & Frequency & $\%$ \\
\hline \multicolumn{3}{|l|}{ 1. Gender } \\
\hline Male & 67 & 69,1 \\
\hline Female & 30 & 30,9 \\
\hline \multicolumn{3}{|l|}{ 2. Age } \\
\hline$<30$ Years & 11 & 11,3 \\
\hline $30-40$ years & 45 & 46,4 \\
\hline 41-50 Years & 32 & 33 \\
\hline$>50$ Years & 9 & 9,3 \\
\hline \multicolumn{3}{|l|}{ 3. Service Years } \\
\hline $0-5$ Years & 11 & 11,3 \\
\hline 6-10 Years & 18 & 18,6 \\
\hline 11-15 Years & 35 & 36,1 \\
\hline 16-20 Years & 22 & 22,7 \\
\hline 21-25 Years & 8 & 8,2 \\
\hline$>25$ Years & 3 & 3,1 \\
\hline \multicolumn{3}{|l|}{ 4. Education } \\
\hline Diploma & 13 & 13,4 \\
\hline Bachelor Degree & 74 & 76,3 \\
\hline Master Degree & 10 & 10,3 \\
\hline \multicolumn{3}{|l|}{ 5. Position } \\
\hline Supervisor & 29 & 29,9 \\
\hline Sect. Head & 18 & 18,6 \\
\hline Ass. Manager & 24 & 24,7 \\
\hline Manager & 22 & 22,7 \\
\hline GM & 4 & 4,1 \\
\hline
\end{tabular}


Berdasarkan Hsail uji deskriptif responden, didapatkan mayoritas hasil sebagai berikut: Jenis kelamin mayoritas pria $(69,1 \%)$, usia responden mayoritas 30-40 tahun $(46,4 \%)$, masa kerja mayoritas 11-15 tahun $(36,1 \%)$, Pendidikan mayoritas sarjana $(76,3 \%)$, posisi mayoritas Supervisor $(29,9 \%)$.

\subsection{Outer Model Analysis Result}

\subsubsection{Convergent Validity}

Hasil convergent validity indikator dari tiap variabel adalah sebagai berikut; variabel kompetensi dengan indikatornya COM1, COM2, COM3, COM4, COM5 dan COM 6 masing-masing 0.734, 0.823, 0.657, 0.717, 0.688 dan 0.793. Variabel manajemen pengetahuan dengan indikatornya KM1, KM2, KM3, KM4, KM5 dan KM6 masingmasing $0.777,0.795,0.799,0.820,0.817$ dan 0.801 . Variabel keunggulan bersaing dengan indikatornya CA1, CA2, CA3, CA4 dan CA5 masing-masing 0.809, 0.697, 0.911, 0.774 dan 0.842 . Variabel Kinerja organisasi dengan indikatornya OP1, OP2, OP3, OP4 dan OP5 masing-masing 0.745, 0.822, 0.756, 0.812, dan 0.869. Hasil uji loading indikator direkomendasikan untuk berada diatas 0,70, Namun selama model masih dalam tahap pengembangan, maka nilai loading indikator 0,60 masih ditoleransi. Dari hasil uji diatas menunjukan bahwa masing-masing indikator dari tiap variabel kompetensi, manajemen pengetahuan, keunggulan bersaing dan kinerja organisasi menunjukan hasil di atas 0,60.

\subsubsection{Composite Reliability}

Table 2

Value of Composite Reliability

\begin{tabular}{|l|l|}
\hline Construct & Composite Reliability \\
\hline Competence & 0,877 \\
\hline Competitive Advantage & 0,904 \\
\hline Knowledge Management & 0,915 \\
\hline Organizational Performance & 0,900 \\
\hline
\end{tabular}

Nilai composite reliability yang diharapkan dari hasil uji adalah ditas 0,70 yang menggambarkan tiap indikator memiliki konsistensi yang tinggi untuk mengukur variabel laten. Hasil penelitian menunjukan masing-masing construct memiliki nilai composite reliability diatas 0,70 yang menandakan konsistensi construct untuk mengukur variabel laten tinggi. 


\subsubsection{Average Variance Extracted (AVE)}

Table 3

Average Variance Extract

\begin{tabular}{|l|l|}
\hline Construct & AVE \\
\hline Competence & 0,544 \\
\hline Competitive Advantage & 0,656 \\
\hline Knowledge Management & 0,642 \\
\hline Organizational Performance & 0,643 \\
\hline
\end{tabular}

Nilai AVE menunjukan nilai varians pada masing-masing indikator dalam konstruk yang ditangkap oleh varaiabel tersebut lebih banyak dibandingkan dengan varians yang diakibatkan oleh kesalahan pengukuran. Nilai AVE yang direkomendasikan adalah > 0,5. Dari hasil analisa didapatkan nilai AVE untuk masing-masing konstruk lebih besar dari 0,50 .

\subsubsection{Cronbach's Alpha}

\section{Table 4}

\section{Cronbach's Alpha}

\begin{tabular}{|l|l|}
\hline Construct & Cronbach's Alpha \\
\hline Competence & 0,9738 \\
\hline Competitive Advantage & 0,9419 \\
\hline Knowledge Management & 0,9863 \\
\hline Organizational Performance & 0,9482 \\
\hline
\end{tabular}

\subsection{Inner Model Test Result}

\subsubsection{Goodness of fit test}

Hasil uji goodness of fit test didapatkan nilai R2 untuk construct keunggulan bersaing sebesar 0,651 yang dapat diinterpretasikan bahwa kompetensi dan maanjemen pengetahuan memiliki pengaru trehadap keunggulan bersaing sebesar $65,1 \%$ sedangkan sisanya sebesar $34,9 \%$ dipengaruhi oleh variabel lainnya. Sedangkan untuk milai R2 construct kinerja organisasi memiliki R2 sebesar 0,678 yang artinya, kinerja organisasi dipengaruhi oleh variabel laten keunggulan bersaingm kompetensi dan manajemen pengetahuan sebesar $67,8 \%$ sedangkan sisanya $32,2 \%$ dipengaruhi oleh variabel lainnya. 
Table 5

Value of R-Square

\begin{tabular}{|l|l|}
\hline Construct & R-Square \\
\hline Organizational Performance & 0,678 \\
\hline Competitive Advantage & 0,651 \\
\hline
\end{tabular}

\subsubsection{Hypothesis Test}

Untuk menjawab hipotesis yang telah maka dilihat signifikansi pengaruh antar construct independent terhadap dependen pada taraf signifikansi 5\%. Hasil nilai TStatistik adalah sebagai berikut:

Tabel 6

Coefficients value (Original Sample), Standard Error and T-Statistics

\begin{tabular}{|l|c|c|c|c|l|}
\hline \multicolumn{1}{|c|}{ Significance Test } & $\begin{array}{c}\text { Original } \\
\text { Sample } \\
(\mathbf{O})\end{array}$ & $\begin{array}{c}\text { Standard } \\
\text { Error } \\
(\text { STERR })\end{array}$ & $\begin{array}{c}\text { T Statistics } \\
(\mid \mathbf{O} / \text { STERR })\end{array}$ & P Values & Result \\
\hline $\begin{array}{l}\text { Competence -- > } \\
\text { Competitive Advantage }\end{array}$ & 0,206 & 0,094 & 2,196 & 0,029 & Significant \\
\hline $\begin{array}{l}\text { Competence -- } \\
\text { Organizational } \\
\text { Performance }\end{array}$ & 0,212 & 0,126 & 1,979 & 0,046 & Significant \\
\hline $\begin{array}{l}\text { Competitive Advantage - } \\
->\text { Organizational } \\
\text { Performance }\end{array}$ & 0,532 & 0,018 & 4,494 & 0,000 & Significant \\
\hline $\begin{array}{l}\text { Knowledge Management } \\
--->\text { Competitive } \\
\text { Advantage }\end{array}$ & 0,653 & 0,080 & 8,173 & 0,000 & Significant \\
\hline $\begin{array}{l}\text { Knowledge Management } \\
-->\text { Organizational } \\
\text { Performance }\end{array}$ & 0,571 & 0,112 & 5,103 & 0,000 & Significant \\
\hline
\end{tabular}

\section{Hypothesis 1}

Hasil pengujian Bootsraping didapatkan nilai koefisien variabel laten kompetensi terhadap keunggulan bersaing sebesar 0,206 menunjukan kompetensi memiliki pengaruh positif terhadap keunggulan bersaing. Sedangkan untuk nilai T-Statistik didapatkan nilai 2,196 dimana nilai ini lebih besar dari 1,96 dan nilai P Values 0,0296 lebih kecil dari 0,05 yang menandakan kompetensi memiliki pengaruh signifikan terhadap keunggulan bersaing, shingga H1 pada penelitian ini dapat diterima. Signifikansi ini sejalan dengan hasil penelitian Ismail et al (2014) yang menunjukan hasil hubungan yang signnifikan anatara kompetensi terhadap keunggulan bersaing pada perusahaan kecil dan menengah 
(SMEs), demikian juga dengan hasil penelitian Hastjarjo et al (2016) yang menunjukan hasil sama pada industry real estate. Sementara Agha et al (2012) dan Jamhour dan Agha (2010) menunjukan hasil yang sama pada industry painting.

\section{Hypothesis 2}

Hasil pengujian Bootsraping didapatkan nilai koefisien variabel laten manajemen pengetahuan terhadap keunggulan bersaing sebesar 0,653 menunjukan kompetnesi memiliki pengaruh positif terhadap keunggulan bersaing. Sedangkan untuk nilai TStatistik didapatkan nilai 8,173 dimana nilai ini lebih besar dari 1,96 dan nilai P Values 0,000 lebih kecil dari 0,05 yang menandakan manajemen pengetahuan memiliki pengaruh signifikan terhadap keunggulan bersaing, shingga $\mathrm{H} 2$ pada penelitian ini dapat diterima. Signifikansi ini sejalan dengan hasil penelitian yang dilakukan oleh Mahdi et al (2018) yang penilitiannya dilakukan pada universitas dalam hubungannya dengan industri sebagai pengguna. Sedangkan Kusuma dan Devie (2013) menunjukan hasil hubungan yang sama dimana penelitiannya dilakukan terhadap 100 manajerial perusahaan swasta yang ada di Surabaya. Sedangkan hasil penelitian Nazarpour dan Shirin (2017) menunjukan hasil yang sama juga namun pada industri pelabuhan yang ada di Iran. Almasi dan Pirzad (2017), menunjukan hasil hubungan yang sama antara manajemen pengetahuan terhadap keunggulan bersaing pada industri perbankan dan Lee et al (2016) pada perusahaan kecil dan menengah (SMEs) di Malaysia.

\section{Hypothesis 3}

Hasil pengujian Bootsraping didapatkan nilai koefisien variabel laten keunggulan bersaing terhadap kinerja organisasi sebesar 0,532 menunjukan keunggulan bersaing memiliki pengaruh positif terhadap kinerja organisasi. Sedangkan untuk nilai T-Statistik didapatkan nilai 4,494 dimana nilai ini lebih besar dari 1,96 dan nilai P Values 0,000 lebih kecil dari 0,05 yang menandakan keunggulan bersaing memiliki pengaruh signifikan terhadap kinerja organisasi, shingga H3 pada penelitian ini dapat diterima. Signifikansi ini sejalan dengan hasil penelitian yang dilakukan oleh Cantele dan Zardini (2018) menunjukan hasil yang signifikan terhadap industri kecil dan menengah yang ada di Italia, sedangkan Lorenzo et al (2017) pada industri Wine yang ada di Spanyol, Othman et al (2015) pada koperasi yang terregistrasi di Malaysia, Kusuma dan Devie (2013) pada perusahaan swasta yang ada di Surabaya, dan Gyampah dan Acquaah (2008) pada perusahaan yang terdapat di Ghana. 


\section{Hypothesis 4}

Hasil pengujian Bootsraping didapatkan nilai koefisien variabel laten kompetensi terhadap kinerja organisasi sebesar 0,212 menunjukan kompetensi memiliki pengaruh positif terhadap kinerja organisasi. Sedangkan untuk nilai T-Statistik didapatkan nilai 1,979 dimana nilai ini lebih besar dari 1,96 dan nilai P Values 0,046 lebih kecil dari 0,05 yang menandakan kompetensi memiliki pengaruh signifikan terhadap kinerja organisasi, shingga H4 pada penelitian ini dapat diterima. Signifikansi ini sejalan dengan hasil penelitian yang dilakukan oleh Otoo dan Mishra (2018) menunjukan hasil yang signifikan terhadap industri perhotelan di India, sedangkan Hastjarjo et al (2016) pada industri Real estate di Indonesia, Nimsith et al (2016) pada industri perbankan di Srilangka, Agha et al (2012) dan Jamhour dan Agha (2010) pada industri painting di UEA. Hasil ini menunjukan bahwa kompetensi merupakan prediktor bagi kinerja organisasi yang dapat meningkatkan komitmen karyawan terhadap perusahaannya, kinerja ekonomi, kinerja sosial dan kinerja lingkungan.

\section{Hypothesis 5}

Hasil pengujian Bootsraping didapatkan nilai koefisien variabel laten kompetensi terhadap kinerja organisasi sebesar 0,571 yang menunjukan kompetensi memiliki pengaruh positif terhadap kinerja organisasi. Sedangkan untuk nilai T-Statistik didapatkan nilai 5,103 dimana nilai ini lebih besar dari 1,96 dan nilai P Values 0,000 lebih kecil dari 0,05 yang menandakan manajemen pengetahuan memiliki pengaruh signifikan terhadap kinerja organisasi, shingga H5 pada penelitian ini dapat diterima. Signifikansi ini sejalan dengan hasil penelitian yang dilakukan oleh Meiranto et al (2012) menunjukan hasil yang signifikan terhadap industri perbankan di Indonesia, sedangkan Almudallal et al (2015) pada sektor publik di Palestina, Nowacki dan Bachnik (2015) pada perusahaan swasta di Polandia dan Muthuveloo et al (2017) pada industri manufaktur lokal dan asing yang teregister di Federation of Malaysian Manufacturers. Hasil ini menunjukan bahwa manajemen pengetahuan merupakan prediktor bagi kinerja organisasi.

\section{Keunggulan bersaing sebagai variabel mediator}

a. Koefisien tidak langsung dari kompetensi terhadap kinerja organisasi melalui keunggulan bersaing adalah $0.206 \times 0.532=0.1096$. perhitungan nilai $\mathrm{Z}$ menggunakan Sobel test didapatkan sebagai berikut: 


$$
\begin{aligned}
& z=\frac{a b}{\sqrt{\left(b^{2} S E_{a}^{2}\right)+\left(a^{2} S E_{b}^{2}\right)}} \\
& z=\frac{0.206 \times 0.532}{\sqrt{\left(0.206^{2} \times 0.094^{2}\right)+\left(0.532^{2} \times 0.018^{2}\right)}} \\
& z=\frac{0.1096}{\sqrt{0.00045}} \\
& z=5.48
\end{aligned}
$$

Dimana :

$\mathrm{a}=$ Koefisien pengaruh kompetensi terhadap keunggulan bersaing

$\mathrm{b}=$ Koefisien pengaruh keunggulan bersaing terhadap kinerja organisasi

$\mathrm{SE}_{\mathrm{a}}=$ standard error kompetensi terhadap keunggulan bersaing

$\mathrm{SE}_{\mathrm{b}}=$ standard error keunggulan bersaing terhadap kinerja organisasi

Dengan nilai $\mathrm{Z}$ score 5.48 lebih besar dibandingkan dengan $\mathrm{Z} 1.98$ maka dapat disimpulkan bahwa keunggulan bersaing mampu memediasi hubungan antara kompetensi dengan kinerja organisasi.

b. Koefisien tidak langsung dari manajemen pengetahuan terhadap kinerja organisasi melalui keunggulan bersaing adalah 0.206 × $0.532=0.1096$. perhitungan nilai $\mathrm{Z}$ menggunakan Sobel test didapatkan sebagai berikut:

$$
\begin{gathered}
z=\frac{a b}{\sqrt{\left(b^{2} S E_{a}^{2}\right)+\left(a^{2} S E_{b}^{2}\right)}} \\
z=\frac{0.653 \times 0.532}{\sqrt{\left(0.532^{2} \times 0.080^{2}\right)+\left(0.653^{2} \times 0.018^{2}\right)}} \\
z=\frac{0.3474}{\sqrt{0.0019}} \\
z=7.89
\end{gathered}
$$

Dimana :

$\mathrm{a}=$ Koefisien pengaruh kompetensi terhadap keunggulan bersaing

$\mathrm{b}=$ Koefisien pengaruh keunggulan bersaing terhadap kinerja organisasi

$\mathrm{SE}_{\mathrm{a}}=$ standard error kompetensi terhadap keunggulan bersaing

$\mathrm{SE}_{\mathrm{b}}=$ standard error keunggulan bersaing terhadap kinerja organisasi 
Dengan nilai Z score 7.89 lebih besar dibandingkan dengan Z 1.98 maka dapat disimpulkan bahwa keunggulan bersaing mampu memediasi hubungan antara manajemen pengetahuan dengan kinerja organisasi.

\section{KESIMPULAN, IMPLIKASI DAN SARAN}

Peran keunggulan bersaing terhadap kinerja organisasi sangatlah penting, hal ini dapat dibuktikan dimana keunggulan bersaing mampu meningkatkan pengaruh dari kompetensi dan manajemen pengetahuan terhadap kinerja organisasi. Kompetensi memberikan efek positif dan signifikan baik terhadap keunggulan bersaing maupun terhadap kinerja organisasi, begitupula dengan manajemen pengetahuan yang memiliki pengaruh positif dan signifikan terhadap keunggulan bersaing dan kinerja organisasi.

Penelitian ini memberikan implikasi bagi para manajer dan pemegang control dalam perusahaan untuk dapat meningkatkan kompetensi dari SDM yang ada dengan menggunakan dimensi yang ada berupa kompetensi professional, kompetensi inti dan kompetensi pembeda yang bersifat unik. Dengan melakukan peningkatan terhadap ketiga kompetensi ini maka akan mampu meningkatkan kinerja perusahaan dari aspek komitmen, kinerja ekonomi, kinerja sosial dan kinerja lingkungan. Implikasi lainnya adalah terkait dengan manajemen pengetahuan yang dapat dijadikan prediktor bagi manajer perusahaan yang pada penelitian ini digambarkan kedalam dimensi identifikasi pengetahuan, penciptaan pengetahuan, penyimpanan pengetahuan, sharing pengetahuan dan penggunaan pengetahuan. Dengan adanya manajemen yang baik terhadap pengetahuan merupakan modal penting bagi perusahaan dalam menghadapi revolusi industri 4.0 yang mengarah kepada ekonomi berbasis pengetahuan. Penelitian ini bukan tanpa kekurangan, mengingat terbatasnya jumlah responden dan variabel yang digunakan. Diharapkan penelitian lanjutan dapat diteruskan dengan menggunakan variabel yang lebih komperhensif berdasarkan teori RBV dan juga dengan jumlah sample yang lebih banyak dari penelitian ini.

\section{DAFTAR PUSTAKA}

Adiputra, I.P.P., Mandala, K., 2017. Pengaruh Kompetensi dan Kapabilitas Terhadap Keunggulan Kompetitif dan Kinerja Perusahaan. E-Jurnal Manajemen Unud. 6(11): 6090-6119. 
Agha, S., Alrubaiee, L., Jamhour, M., 2012. Effect of Core Competence on Competitive Advantage and Organizational Performance. International Journal of Business and Management. 7(1): 192-204.

Almasi, F., Pirzad, A., 2017. The Effect of Intellectual Capital and Knowledge Management on Competitive Advantage: Testing the Mediating Role of Customer Relationship Management. International Journal of Economic Perspective. 11(3): 895-904.

Almudallal, A.W., Bakri, N., Muktar, S.N., El-farra, M.M., 2015. Implementing Knowledge Management in the Palestinian Public Sector Institutions: Empirical Study on the Presidency of the Palestinian Government. International Review of Management and Marketing. 6(S4): 101-107.

Al-Refaie, A., Al-Tahar, M., 2015. Effect of Knowledge Management and Organizational Learning on Firm Performance. Journal of Nature Science and Sustainable technology. 8(3): 369-390.

Ansoff, I. Corporate Strategy. New York: McGraw-Hill, 1965.

Awaad, A.S., Al khattab, A.A., Anchor, J.H., 2013. Competitive Priorities and Competitive Advantage in Jordanian Manufacturing. Journal of Service Science and Management. 6: 69-79.

Banerjee, P., 2003. Resource Dependence and Core Competence: Insights from Indian Software Firms, Technovation, 23: 251-263

Barney, J., 1991. Firm Resources and Sustained Competitive Advantage. Journal of Management. 17(1): 99-120.

Cahyaningsih, E., Sensuse, D.A., Arymurthy, A.M., Wibowo, W.C., 2017. NUSANTARA: A New Model of Knowledge Management in Government Human Capital Management. Procedia Computer Science. 124: 61-68.

Cantele, S., Zardini, A., 2018. Is sustainability a competitive advantage for small businesses? An empirical analysis of possible mediators in the sustainabilityefinancial performance relationship. Journal of Cleaner Production. 182: 166-176.

Chen, Y. F., Wu, T. C., 2007. An empirical analysis of core competence for high-tech firms and traditional manufacturers. Journal of Management Development, 26, 2, 159-168.

Deeds, D.L., Hill, C.W.L., 1996. Strategic Alliances and the Rate of New product Development: An Empirical Study of Entrepreneurial biotechnology Firms. Journal of Business Venturing. 11: 41-55.

Ding, H., Fu, Y., Zheng, L., Yan, Zh., 2018. Determinants of the competitive advantage of dairy supply chains: Evidence from the Chinese dairy industry. International Journal of Production Economics. 1-42.

Emilia, H., 2015. The importance of the manufacturing sector in the Romanian economy. Procedia Technology. 22: 976-983.

Ferdinand, A. 2002. Structral Equation Modelling dalam penelitian manajemen. Semarang: FE UNDIP. 
Friedlander, F., Pickle, H., 1968. Components of Effectiveness in Small Organizations. JSTOR. 13(2): 289-304.

Garcia, C.Q., Velasco, C.A.B., 2008. Innovative competence, exploration and exploitation: The influence of technological diversification. Research Policy. 37: 492-507.

Gautam, D.K., Ghimire, S.B., 2016. Psychological empowerment of employees for competitive advantages An empirical study of Nepalese service sector. International Journal of Law and Management. 59(4): 466-488.

Gyampah, K.A., Acquaah, M., 2008. Manufacturing strategy, competitive strategy and firm performance: An empirical study in a developing economy environment. International Journal of Production Economics. 111: 575-592.

Hafeez, K., \& Abdelmeguid, H., 2003. Dynamics of human resource and knowledge management. Journal of the Operational Research Society, 54(12), 153-164.

Hameed, Imran. 2009. Sources of Business Competitive Advantage: A Review. Journal of Business \& Economics. 222-233.

Hamel, G. dan Prahalad, C.K. 1994. Competing for The Future. Boston : Harvard Business School Press.

Hastjarjo, K., Yahya, D.K., Afiff, F., Rufaidah, P., 2016. Core Competence on Real Estate Industry in Globalization Phenomenon: A Contemporary Approach. International Journal of Economics and Financial Issues. 6(5): 14-19.

Hazen, B.T., 2015. Knowledge Management for Logistic Service Providers: The Rule of Learning Culture. Industrial Management and Data System. 116(3): 584-602

Hellriegel, D dan Slocum, J. W. (2011). Organizational Behavior. Mason: SouthWestern, Cengage Learning.

Hertati.L. 2015. Total Quality Management As Technics on Strategic Management Accounting. International Journal of Recent Advances in Multidisciplinary Research Vol. 02, Issue 11, pp.0942-0949, November, 2015

Hertati, L.2015. Internal Control And Ethics Of Quality Management Accounting Information Systems And Implications On The Quality Of Accounting Information Management: Proposing A Research Framework. International Journal of Economics, Commerce and Management United Kingdom Vol. III, Issue 6, June 2015 Licensed under Creative Common Page 902 http://ijecm.co.uk/ ISSN 23480386

Hertati.L. 2016. Just In Time, Value Chain, Total Quality Management, Part Of Technical Strategic Management Accounting. International Journal of Scientific \& Technology Research Volume 5, Issue 04, April 2016 Issn 2277-8616

Hertati, and Sumantri 2016. Just In Time, Value Chain, Total Quality Management, Part Of Technical Strategic Management Accounting.International Journal Of Scientific \& Technology Research Volume 5, Issue 04, April 2016 Issn 22778616.

Hertati.L. 2019. The Effect of Human Resource Ethics on Financial Reporting Implications for Good Government Governance (Survey of Related Sub-units in 
State-owned Enterprises in SUMSEL). International Journal of Economics and Financial Issues ISSN: 2146-4138 available at http: www.econjournals.com International Journal of Economics and Financial Issues, 2019, 9(4), 267-276

Hertati.L.2019. Impact Of Business Strategy On The Management Accounting: The Case Impact Of Business Strategy On The Management Accounting: The Case Sumatra. Journal of Asian Business Strategy. 9(1).29.39

Ismail, M.D., Domil, A.K.A., Isa, A.M., 2014. Managerial Competence, Relationship Quality and Competitive Advantage among SME Exporters.Procedia Social and Behavioral Sciences. 115: 138-146.

Iuliana, E., Criveanu, M., 2016. Financial and Non Financial Indicators For Organizational Performance Measurement. Faculty of Economics and Administration, Romania. 1-12.

Jamhour, M.S., Agha, S.H., 2010. The Impact of Core Competence on Organizational Performance. Middle East university. 1-134.

Jenatabadi, H.S., 2015. An Overview of Organizational Performance Index: Definitions and Measurements. International Journal of Business and Management. 8(19): 107-117.

Kerlinger, F.N. 2000. Azas-azas penelitian behavioral. Yogyakarta: Gajah Mada University Press.

Khan, R.A. (2012). Knowledge Management: A Framework for Competitive Advantage. Global Journal for Information Technology and Computer Science, vol. 1 (1).1

Ko, W.H., 2015. Constructing a professional competence scale for foodservice research\& development employees from an industry viewpoint. International Journal of Hospitality Management. 49: 66-72

Kusuma, F.S.D., Devie, 2013. Analisa Pengaruh Knowledge Management terhadap Keunggulan Bersaing dan Kinerja Perusahaan. Business Accounting Review. 1(2): 161-171.

Lee, V.H., Foo, A.T.L., Leong, L.Y., Ooi, K.B., 2016. Can Competitive Advantage be Achieved Through Knowledge Managemen A Case study on SMEs. 144.Leonard-Barton, D. 1992. Core capabilities and core rigidities: A paradox in managing new product development. Strategic Management Journal, 13: 111125.

Li, D.Y., Liu, J., 2012. Dynamic capabilities, environmental dynamism, and competitive advantage: Evidence from China. JBR Journal of Business Research. 1-7.

Li, S., Nathan, B.R., Nathan, T.S.R., Rao, S.S., 2006. The impact of supplychain management practices on competitiveadvantage and organizational performance. The International Journal of Management and Science. 34: 107-124.

Ling, T.N., Yih, G.C., Eze, U.C., Gan, G.G.G., Ling, L.P., 2008. Knowledge Management Drivers for Organizational Competitive Advantage. Proceeding of Applied international Business Conference. 501-510.

Lopez. S.P., Alegre, J., 2011. Information technology competency, knowledge processes and firm performance. Emerald Insight. 112(4): 644-662. 
Lorenzo, J.R.F., Rubio, M.T.M., Garces, S.S., 2018. The competitive advantage in business, capabilities and strategy. What general performance factors are found in the Spanish wine industry?. Science Direct. 1-15.

Lysaght, R.M., Altschuld, J.W., Grant, H.K., Henderson, J.L., 2001. Variables Affecting the Competency Maintenance Behaviors of Occupational Therapists. AOTA. 55: $1-8$.

MacLeod, A.K., Conway, C., 2007. Well-being and positive future thinking for the self versus others. Psychology Press. 21(5): 1114-1124.

Mahdavi, M.A.P., Pirzad, A., 2017. Study on Effect of Intellectual Capital on Knowledge Sharing. International Business Management. 11(3): 814-820.

Mahdi, O.R., Nassar, I.A., Almsafir, M.K., 2018. Knowledge management processes and sustainable competitive advantage: An empirical examination in private universities. Journal of Business Research. 2(13): 1-15.

Mansfield, R.S., Busse, T.V., Kreplka, E.J., 1978. The Effectiveness of Creativity Training. Review of Educational Journal.

McCelland, D.C. 1973. Testing for Competence Rather than for Intelligence. American Psychologist. 1-14.

McFadyen, M.A., Canella Jr, A.A., 2004. Social Capital and Knowledge Creation: Diminishing Returns of the Number and Strength of Exchange. Academy of Management. 47(5): 735-746.

Meiranto, W., Puspitasari, E., Sari, I.M., 2012. Pengelolaan Knowledge Management Capability Dalam Memediasi Dukungan Information technologies Relatedness Terhadap Kinerja Perusahaan: Pendekatan Reflective Second Order Factor. Jurnal Akuntansi AKRUAL. 3(2): 114-129.

Morin, E.M., Audebrand, L.K., 2014. Organizational Performance and Meaning of Work: Correcting for Restricted Range. Organizational Performance and Meaning of Work. 1-19.

Munir, N.S., 2011. Penerapana Manajemen Pengetahuan di Perusahaan Indonesia. PPM of School Management. 1-13.

Muthuveloo, R., Shanmugam, N., Teoh, A.P., 2017. The impact of tacit knowledge management on organizational performance: Evidence from Malaysia. Asia Pacific Management Review. 1-10.

Nazarpour, M., Shirin, Z.B., 2017. Relation among Processes of Human Resources and Obtaining the Organizational Axial Capability with Intermediation Role of Knowledge Management Based on Modeling Structural Equations (Case Study: Khuzestan General Directorate of Ports and Maritime - Special Economic Zone of the Imam Khomeini Port). International Review of Management and Marketing. 7(3): 77-85.

Nimsith, S.I., Rifas, A.H., Cader, M.J.A., 2016. Impact of Core Competency on Competitive Advantage of Banking Firms in Sri Lanka. International Journal of Science Research and Innovative Technology. 3(7): 64-72. 
Nowacki, R., Bachnik, K., 2015. Innovations within knowledge management. Journal of Business Research. 1-5.

Othman, R., Arshad, R., Aris, N.A., Arif, S.M.H., 2015. Organizational Resources and Sustained Competitive Advantage of Cooperative Organizations in Malaysia. Procedia Social and Behavior sciences. 170: 120-127.

Otoo, F.N.K., Mishra, M., 2018. Impact of Human Resource Management (HRM) Practices on Hotel Industry's Performance: The Mediating role of Employee Competencies. Indian Journal of Commerce \& Management Studies. 9(2): 17-29.

Penrose, E.T., 1959. The Theory of the Growth of the Firm. Oxford University Press: Oxford

Porter, M.E., 1985. Competitive Advantage: Creating and Sustaining Superior Performance: with a new introduction. The Free Press. New York, USA.

Sanchez, R. \& Heene, A. (1997). Reinventing strategic management: New theory and practice for competence-based competition, European Management Journal, 15(3), 303-317.

Srivastava, S.C., 2005. Managing Core Competence of the Organization. VIKALPA. 30(4): 49-63.

Stefanikova, L., Masarova, G., 2014. The need of complex competitive intelligence. Procedia Social and Behavior Sciences. 110: 669-677.

Stoner, C.R., 1987. Distinctive Competence and Competitive Advantage. Journal of Small Business Management. 25(2): 33-39.

Sulistyandari dan Handayani, 2011. Membangun Keunggulan Bersaing Berkelanjutan: Sebuah Kajian Literatur Pada Konteks Usaha Kecil dan Menengah. Jurnal Ekonomi Bisnis dan Akuntansi. 1 (1): 1-15.

Tsou, H.T., Chen, J.S., Liao, W.H., 2014. Market and technology orientations for service delivery innovation: the link of innovative competence. Journal of Business \& Industrial Marketing. 29(6): 499-513.

Turulja, R., Bajgoric, N., 2018. Knowing Means Existing: Organizational Learning Dimensions and Knowledge Management Capability. De Gruyter. 9(1): 1-19.

Zaied, A.N.H., Hussein, G.S., Hassan, M.M., 2012. The Role of Knowledge Management in Enhancing Organizational Performance. International Journal of Information Engineering and Electronic Business. 1-10. 